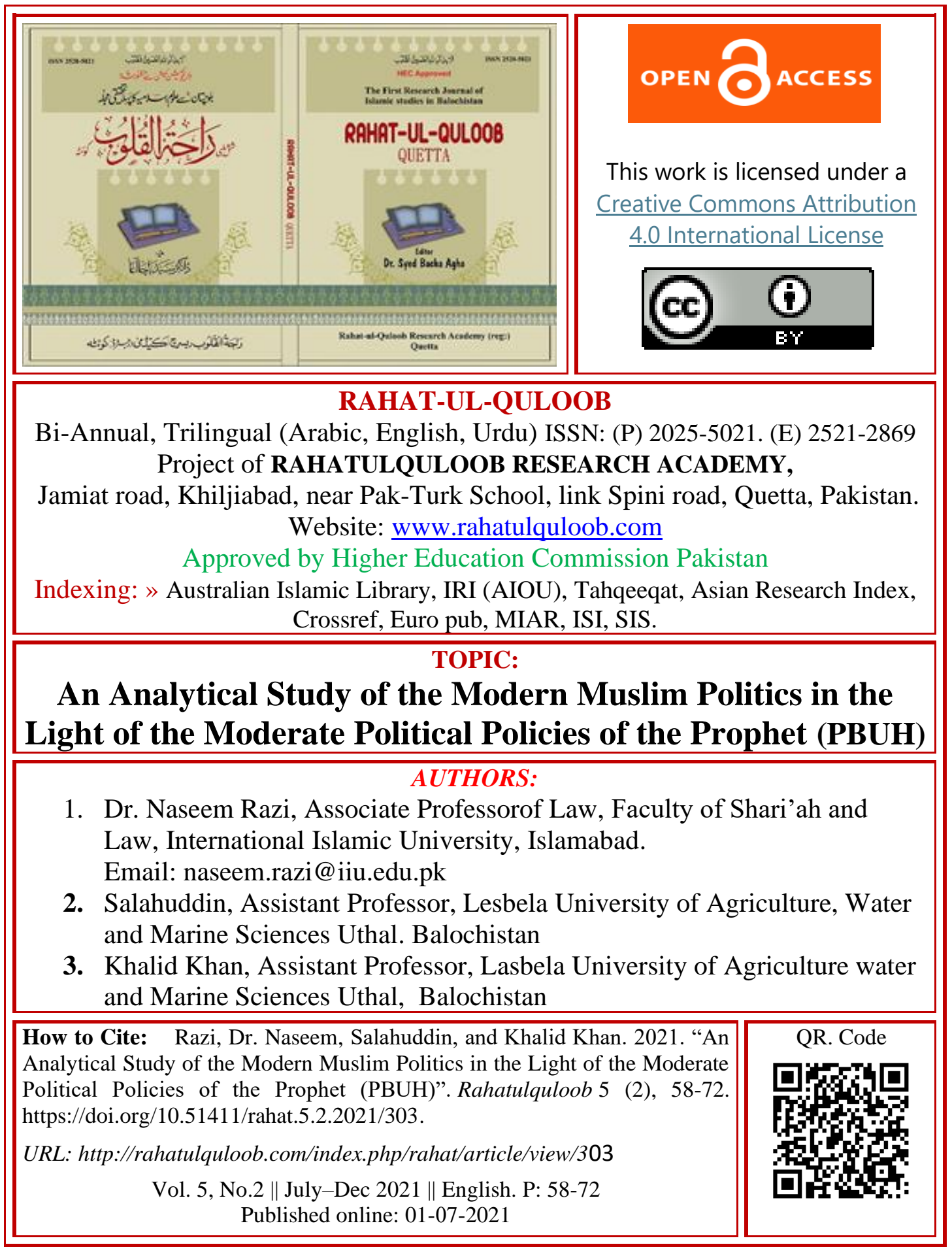




\section{An Analytical Study of the Modern Muslim Politics in the Light of the Moderate Political Policies of the Prophet (PBUH)}

${ }^{1}$ Naseem Razi, ${ }^{2}$ Salahuddin, ${ }^{3}$ Khalid Khan

\section{ABSTRACT:}

This research aims to discuss the contemporary situation of modern Muslim politics in the light of the political vision of the Prophet (pbuh). It explores that contrary to the prevailing system of the world politics which was based on the religious and ethnic prides, injustice and class system, the Holy Prophet (pbuh) introduced the concept of moderate politics by establishing the principles of harmony, reconciliation and admiration of other religions that resulted in the economic prosperity and political stability of the whole nation. However, the contemporary Muslim world seems upset regarding its political policies and suffering from the issues of extremism, religious conflicts, sectarianism, and lack of reconciliation that put the modern Muslim world into chaos and law and order situation. This research thus, concludes that all this because of the ignorance of the moderate politics of the Prophet (pbuh). It suggests following the political steps of our Last Prophet (pbuh) to achieve economic prosperity and political stability in the Muslim states.

Key words: World Politics, Medieval history, Politics of Muhammad (pbuh), Modern Muslim politics, conclusions and recommendations

\section{Introduction}

The term moderate politics is an innovation introduced by some political reformers of the modern world (Morrison \& Melleson, 2004). It is defined in the meaning of a political belief between two extremes of political ideas, i.e., liberalism and conservatism (Steven Fish,2012). Steven applies the term moderate on a person who opens to listening to the truths of others and to consider their importance" (p.67). In the political history of the modern world, Benjamin Franklin, a politician used the term moderate politics in 1787 at the time of drafting the constitution by calling all the parties to adopt moderate policy to reconcile for a greater cause (Brands,2000). Recently, a group of social activists of USA launched a campaign in 2000 for "moderate politics" to avoid radical extremes of political parties (Steven, p.213). Talking about the objectives of moderate politics, it aims Participation of all political parties in law making process and in the affairs of the state. It also aims to achieve human development, social justice, economic growth and peace in a particular society ((Brands, p.56). Looking into the contemporary situation of the political development of the contemporary Muslim world, it leads that the contemporary Muslim world has no scientific guideline to establish political stability and to achieve economic prosperity. Although, the issue of the role of religion in the political life of the state and the people has been considered as one of the most critical issues of the contemporary political debates yet the politics of the contemporary Muslim world has failed to establish a political system in the light of the political vision of its religion as 
provided by way of revelation and successfully implemented by the Prophet (pbuh). In this context, this research aims to provide an analysis of the political steps taken by the Holy Prophet (pbuh) in due process of politicization of the society at the first Muslim state of Medinah. This article thus, is divided into three sections: Section first throws light on the development of the politics during medieval era before the dawn of Islam; second section discusses the character of the Prophet (pbuh) as a political leader and as a founder of the moderate politics; the last section discusses the contemporary political situation of the Muslim world. In the end, it draws some conclusions and suggests some recommendations.

\section{Section one}

\section{Developments of the Politics during Medieval Era before the Dawn of Islam}

Politics is a process by which a group of people make decisions to achieve control over a human community. It consists of social relations involving jurisdiction and execution (Aristotle, 1967). Literally, the word politics means organization of the affairs of the life of the people (Cowvie, 2010). In the history of the politics, Aristotle was the first one who used the term "politika" in his writings in the meanings of the affairs of the city-state (Aristotle, p.45). Thus, the word politics is a Greek derivation derived from the word "politika", which was Latinized as "polettiques" during the mid of the $15^{\text {th }}$ century (Earner Barker, 2001). Later, in 1520, it was rendered in English as "politics" (Oxford Dictionary, p.678). A political system is a framework, which defines the methods of the politics (Aristotle, p.122).

At the time of the Qur'anic revelation, the Greek civilization was based on the philosophical ideas of Socrates and Plato. That favored the diversity of the human beings with respect to their wisdom and capacity, which leads that God intended to confine the humankind to some specific function and that this principle of natural diversity is in fact, a justification for the establishment of class system in a commonwealth (Aristotle, p.124). The principle of natural diversity led that every member of the society has his specific functions and should confine his activities to the proper discharge of these functions, such as some people have the power to command and have capacity to govern while others are capable of helping those in power to achieve their ends as subordinates of the government. In the same manners, some people are fit to be trades men, or artisans, or soldiers, so they should try to indulge only these activities and should not try to become a governor or to rule others (Bodenheimer,1977). Commands of the sovereign were considered as divine, revealed and unalterable rules among all the traditional societies that could not be refuted or altered even if against justice and equity (Walter Jones, 1956). Like Greeks, the English primitive society was divided into different local folk- assembly at different localities. The whole England was divided in to 'hundreds' which further sub-divide in to "tithing". Each was sovereign in its sphere within its boundaries. Even an English man was not thought himself as English and had not much consciousness beyond his world of his own village. Those "tithings" were consisted of ten national 
families headed by tithing man. The function of the tith man was to administer, to maintain peace and order and to collect taxes for the King (Baker, 1998).

The European states were governed by way of authoritarian political systems and all powers of jurisdiction, execution and implementation were vested in the King. The King was considered as the fountain head of justice and all the issues were dispensed off at his sole discretion (Shabbir Akhtar, 2011). The accused had no right of hearing and justice while dependent upon the wishes and desires of the servants of the King. The rights and interests of the individuals were considered subjugated to the authority's desires and ambitions (Baker, p.212). The whole world of that time could be defined as bipolar world divided between the Christian and Roman on the one hand and Zoroastrian Persia (Iran) on the other. The Abyssinia (Ethiopia) was an independent regional power of the Christians while the Persia was a world stage competitor of the Roman Empire (Walter, p.325). It was at the end of the $4^{\text {th }}$ century (395 A.D.) when the Roman Empire formally split into two empires, the Eastern Roman Empire, and the Western Roman Empire. Each Empire had its own emperor, capital, and governments etc and also resulted in the division of the world into two major parts; the East and the West (Barker, p.41). Culturally, the Easter Roman Empire was more civilized and urbanized than the Western Empire, which was consisted of rural areas with uncivilized culture. Further, both adopted different languages as Easter Roman Empire adopted Greek as their common language while the Western Empire adopted Latin as their national language (Baker, p.277). On the basis of different cultures and languages both Empires started to conflict with each other for the sake of their interests and consequently, became weak internally and externally. In the meantime's, the law was started to be considered as different from religion. Law came to be regarded not as an unchanging command of a divine being but as a purely human invention, born of expediency and alterable at will (Barker, p.188). Politically, the Western Empire had a system of monarchy and most of the time ruled by a military strong man with a title of "Megsiter Militum" or "Patrician" or both and they were usually figureheads, while the Eastern emperors maintained a more democratic political system. However, with the dissolution of the Western Empire during 476500 A.D, the Eastern Roman Empire left only alive. Like Roman, the Persia also adopted a complex and static royal system of politics (Edward Gibben, 1966).

The overall politics of the world was lethargic and consisted of bureaucratic and monarchical form of the governments. The gradual changes from conventional trend of monarchy to contemporary system of states cause the growth of democracy and Parliamentary form of the government. As Shabbir Akhtar (2011) pointed out that: "The democratic institutions of modern western nations established mainly in protest against Christian political norms especially regarding divine rights of king which was immature and immoderate and thus eradicated through revolution or reform" (p.240). It was during the $10^{\text {th }}$ century when a scheme of local government was introduced in England by the monarch in order to maintain law and order at each locality 
(Pollock,1929). During the $16^{\text {th }}$ century, the religion-based states started to dissolve and nation-states started to emerge. This dogma was first introduced in the Peace Treaty of Augsburg in 1555 A.D., and it was claimed that "whoever's region his religion' derived from Latin words "Eius rego, cuius religio" which later on enforced by the Treaty of Westphalia in 1648. These four Latin words in fact led to create the new political map of the modern European by endorsing the disintegration of Christendom into many individual states under sovereign national rulers rather than the single dominion of Catholic Church (Gibben, p.266). In this way, a nation of civilization divided into religious groups and replaced a religious empire into ethnic groups and nations (Shabbir akhtar, p.176). In the same manners, and until the $17^{\text {th }}$ century, English legal system had no concept of separation of power. The judges had to hold position as viceroys of King and the task of the judges was just to help the central state and its legal forms and institutions (Cowine \& Bredny,2003). The idea of independence of judiciary and the legal system from the direct control of the state was presented by English philosopher John Locke who saw it as one of the essential reasons for and justifications of the social contract on which the social structure was assumed to be based (Pollock \& Maitland, p.77).

Likewise, the concept of democratic form of government has its origin in the political struggle started in the late $16^{\text {th }}$ century to establish a system based on the principles of equality, justice, and to clarify the extent of the powers of the state. As David (1997) observed that law, rules and policies appear justified when they are democratic (p.9). All this leads that the medieval political system was based on the authoritarian and monarchical political system and all powers of jurisdiction, execution and implementtation were vested in the King and his servants. Most of the political conflicts were for personal dominance or for the occupation of the world. Every order of the King just or unjust was considered law and was implemented as revealed, unalterable and immutable. Religion also directly or indirectly performed an important role in the development of political system of each society and each nation ever tried to impose its religious norms over all its subjects and there was a common practice of forced conversion of the defeated nation into the religion of defeating nation (Naseem Razi, 2015, p.319). Monarchy was the most favored form of the politics and there was no concept of constitution, democracy or division of power rather all powers were vested in the King and the Crown. The religious scholars and pops had to enjoy unrestricted discretion and were the wealthiest people (Naseem Razi, 2016). Moreover, the political systems had no concern with the issues of the individuals rather worked for the protection of the interests of the King and the Crown. The whole society was divided into different classes and human beings were treated in the light of their wealth and social status in a commonwealth. The ordinary people men, women and saves had no socio-economic rights and were treated badly. There was no concept of socioeconomic justice and economic equilibrium. All means of earning were exploitative by nature that made the rich richer and the poor poorer. Prosperity was confined to 
feudal lords and tenants were considered as slaves. Usury was a common practice and the poor were being exploited in the name of loan. Poverty ratio was very high but prevailing political system had no policy for the eradication of poverty or to ensure justice for poor people, women and children (Naseem Razi, 2016).

\section{Section Two}

\section{Muhammad (pbuh) as Founder of the Moderate Politics}

Before the birth of the last Prophet Muhammad (pbuh), the Arab peninsula was not considered as the direct part of the political system of the world. Arabs had their independent system of politics and no direct relations with the rest of the world.

Makkah which was located in the zone of Hijaz about 1459 Kilometers to the Southeast of Jerusalem and in the Southeast Arabian Desert however, was a famous place of worship and was considered as the oldest place where the first Hadrat Adam (pbuh) constructed the first house of worship on this earth (Ibn Hashsham, 1988). The Holy Prophet (pbuh) was born at Makkah in 569 or 571 A.D as an orphan in the most notable family of Quraysh. It is reported from Abu Hurayrah that the Holy Prophet (pbuh) said: "I have been created by Allah Almighty in the best family (tabaqah) of human beings" (Imam Bukhari, 1989).

The socio-cultural, economic and political environment of Makkah was not different form the rest of the world. The stronger one vigorously practiced the principle of 'Right of Might'. However, the administration of the city-state was stable and different tribes were assigned different administrative functions such as administration of Ka'abah, administration of pilgrimage, and administration of tax to govern the expenditure of the city-state. There was also a counsel named "Dar al-Nadwa" and all the senior citizens were members of that counsel. The function of that counsel was to administer foreign affairs of the state in case of any danger, attack or external aggression. There was an army to protect Makkah. The tribe of the Quraysh was the most powerful and dominant among all and tied the whole society into a peace treaty with them (Muhammad Hameedullah, 1993).

In this way, with respect to political stability, Makkah was strong and the common people did not have courage to oppose Quraysh. In that particular context, Muhammad (pbuh) grew up as the most respectable and pious young man, a young man with the modest behave and antiquates who (pbuh) never worshipped any idol and ever kept himself (pbuh) away from all the types of unethical and immoral practices (Sayyed Suleman Nadwi, 1967). As soon as he (pbuh) grew up, he (pbuh) started to take part in the political activities of the people and started reformation of the corrupt socio-political practices (Naeem Siddique, 1960). His political vision was quite different from the prevailing political system that was based on the principle of ethnic pride and racial dominancy and ever sought to increase conflicts and to create law and order situation even during sacred months or on the occasion of sacred ceremony like Hajj. An example of such type of pride was "Harb al-Fujjar" (battle of Harb) which occurred due to instigating poetry of a poet of Bani Knanah who 
pronounced himself as the most respectable person among all the Arabs and challenged that if some has any objection over his claim then sword would decide the issue" (Ibn Sa'ad, 1388 A.H). Over such an open challenge a person attack over him and this led a series of battle on every hajj for four years between Quraysh, Knanah and Qays and Milan. At that time Muhammad was of 20 years of age but he (pbuh) did not participate in the battle of Fujjar as a fighter rather participated just to help out his uncles in the battle (Ibn Hashsham p.244). It is reported that when some notables of his (pbuh) family suggested reconciliation, he (pbuh) joined it heart heartedly and became an active member of the movement and the treaty of reconciliation titled as "Half al-Fudhul" (Naeem Siddique, p.89). Due to his good moral character and piousness, a long time before his prophet hood, he (pbuh) became famous among the people as the most influential and pious personality of the society and was titled as alSadiq and al-Ameen (SafiurRehman, 1979).At the age of 35, he (pbuh) was appointed as a judge to resolve the issue of "Hijr-e-Aswad" which he (pbuh) held by way of reconciliation among different tribes and thus, confiscated the danger of a great battle among them (Ibn Hashsham, p.189).

At the time of migration towards Yathrib with the permission of Allah almighty, the prophet (pbuh) did not does hasten in migration rather first he (pbuh) held certain meetings with the notables of Yethrib who accepted Islam and invited the Prophet (pbuh) to their city state. Finally, after 13 years of preaching of Islam at Makkah, the Holy Prophet (pbuh) left Makkah and migrated to Madinah (Ibn Sa'd, p.99).

Yethrib was consisted of about thirty independent tribes. Each tribe was an independent and autonomous state and had its own system of administration of justice. Taking about the political situation of Yethrib, it was different from Makkah and a condition of political conflict was existed among different tribes. Most of the tribes remained in a state of constant civil war that had destructed the socio-economic structure of the society. The last destructed war occurred only five years before the arrival of the Prophet (pbuh) at Madinah (Muhammad Hamidullah, p.177). However, Aws and Khuzraj and Jews were the famous and dominant tribes. The Jews were the most powerful people and had a control over Madinah politically and economically. Usury was considered as an economic means of earning (Mubarakpuri, p.233).

After migration, the Holy Prophet (pbuh) first analyzed the political and socio-cultural environment and when found it a city of multi-nations, he introduced and established the principle of harmony and reconciliation (Ibn Hashsham, p.190). The Jews were the most influential nation of Madinah and had their own educational, cultural and economic background and were dominant over others. Being the last Prophet (pbuh) of Allah, he (pbuh) could refute the validity of their religion and book after Islam and Qur'an but he did not do so rather sought friendly relationship with them and gave them respect and equal status to Muslims. He himself went to the Rubbis of Jews to visit them and had to sit with them, eat with them and consult with them (Muhammad Hamidullah, p.217). All that led the Jews to feel content with the Prophet (pbuh) and 
to welcome him (pbuh) as a political leader to lead them. That was a unique example of the political vision of the Prophet (pbuh) that never be witnessed at that time. The politics established by the Prophet (pbuh) was not for personal dominance or for occupation of the world rather it was a moderate politics to establish equality, justice and to introduce natural equality of all human beings despite their differences in status, caste and religion (Naseem Razi, p.313). This concept of politics was quite different from the western concept of the politics which was for place, post and prominence as ambitious people jostle for influential positions (Brierly, 1998). The politics of the Prophet (pbuh) was to establish doctrine of Oneness of God, to declare human being as the most respectful creature of the universe, equality before law and to establish peace and justice around the globe. The political system introduced by the Prophet (pbuh) was indifferent of all types of prides, the ethnic pride, religious pride, pride of worldly success, and the pride of absolute power of monarch etc (Naseem razi, p.115). In this way, the Prophet (pbuh) established the principle of moderate politics by way of reconciliation and harmony and eliminated all types of ethnic and religious pride. A moderate politics that is an innovation of the late $20^{\text {th }}$ century after WWII when some dominant nations of the world suggested for the establishment of United Nation Organization to maintain peace and order, to avoid unnecessary conflict and to resolve the issues of the states by way of reconciliation (Clive Archer, 1989). The political manifesto of the Prophet (pbuh) was based on the universal appeal that all humanity as one community with a common monogenetic origin and a common political future under the Supreme Sovereignty of Allah Almighty (The Qur'an: 4:1). The Prophet (pbuh) first paid attention to manage the issues of muhajirin who were migrated and left everything at Makkah. They were strangers at Madinah and had no food, no shelter and no source of earning. With the help of the Qur'anic provisions and with his unique political vision, the Prophet (pbuh) tied both Muslims of Makkah (muhajirin) and Muslims of Madinah (ansar) into a tie of brother hood on the basis of common religion by way of "Muwakhat al-Madinah. He called upon both ansar and muhajirin and then pronounced by name each of ansar and muhajirin and declared them brother of each other. To fulfill the objectives of that new relationship, the ansar set an unmatchable example of brother hood and offered their brethren to share their properties moveable and immoveable equally. However, due to divine company of the Prophet (pbuh) most of muhajirin preferred to earn and requested them to show them way to market. Consequently, Muwakhat al-Madinah led to increase economic mobility and economic prosperity of the poor and helpless people (Ibn Hashsham p.211). This also lead that to manage the economic needs of the people, means of earning and fulfillment of basic necessities of life are the responsibilities of a state. This political vision of the prophet (pbuh) later on endorsed by the Caliphs and implemented practically (Shibli Nu'mani, 1989). Thus, Muwakhat al-Madinah was the first achievement of the Prophet (pbuh) as the political ruler of the state of Madinah. The other task before the Prophet (pbuh) was to administer justice and to 
establish a peaceful political state at Madinah. To achieve that, the Holy Prophets (pbuh) first ordered his legislative council to draft the Constitution of Madinah and then called upon all the representatives of all the tribes, Muslims, non-Muslims, Jews and Christians and addressed them. In his address, first of all the Prophet (pbuh) drew their attentions to the prevailing weak political condition at Madinah due to their internal conflicts and disunity and that it might cause disintegration of the city state in case of external invasion over Madinah. Then he (pbuh) suggested forming a single government under one administration, which may ensure peace and order, economic progress and protection against all internal and external aggression. After that the Prophet (pbuh) presented before them the draft of the "Constitution of Madinah" which was accepted and signed unanimously by all the tribes of Madinah including Jews (Mubarakpuri, p.166).

By signing the Constitution, all the tribes and the Jews endorsed that all the sovereignty belongs to Allah Almighty and that the Holy prophet (pbuh) is his last messenger as written in Article 57 of the Constitution that "Allah is the protector of the good people and those who fear Allah and Muhammad (PBUH) is the Messenger of Allah". They also agreed upon that the Holy Prophet (pbuh) would be the head of the state and as well as chief justice as practiced in that time. Further, Holy Prophet (pbuh) also introduced the modern concept of one nation based on territory. This is apparent from the wording of Article 1 of the Constitution that leads: "This is a writing (document) from Muhammad (pbuh) the Prophet, between the believers, Muslims of Quraysh and Yathribites and those who followed and fought with them. They will form one Ummah to the exclusion of others (Ibn Ishaq, 1978). This article clearly leads that the Prophet (pbuh) proclaimed the Constitution as head of the state and that all the Muslims and the non-Muslims including all signatories would follow the administrative and economic policies of the Prophet (pbuh) as one nation. This is what we find in the constitutions of the modern states (Skinner, p.88). Like the modern constitutions that constitution was consisted of different provisions dealing with the major administrative issues such as definition of nation, scope of the constitution, sovereignty of Allah Almighty, Prophet hood of the Prophet (pbuh) etc., and as well as responsibilities of all the tribes of Madinah. It also dealt with both civil and criminal issues of the subjects. The content of the modern constitutions/statutes create or identify each

\footnotetext{
* The wording of the address was "You are divided at present into various tribes which are completely independent of each other with the result that in the event of one being attacked by an enemy from without, the rest of you remain neutral and one tribe alone has to face the collective might of the invader. This could lead to defeat and ultimate destruction of all tribes one by one, if they fight the enemy severally. Would not it be better if all of you join to form a single government so that the enemy knows that it would have to face the collective might of all the tribes of Madinah? Here then it is mithaq which will provide safety from the enemy and will help improve the economic and social conditions of all the signatories". Ibn Hashsham. Sirah al-Nabi. Vol. 2.
} 
organ of the state, each agency, describe its decision-making powers and suggest overall goal or guidelines for them to implement the statutory provisions. The legitimacy and operation of a modern state begins and sometimes ends with the official whose job is to apply and interpret the statutes (Roscoe Pond, 1987). This is why the Muslims claim that it is the first written constitution of the world promulgated by the Prophet (pbuh) in the first Muslim state of Madinah (Muhammad Hamidullah, p.199). The constitution of Madinah also leads that Madinah was an independent state and can be characterized as the first democratic state of the modern world (Salmond, 1978). It also leads that there are two main primary objectives of a state: To maintain law and order, to ensure economic equilibrium and to protect its citizen from all types of internal and external aggression. The objectives of a state of $21^{\text {st }}$ century is not different form these objectives expressed by the Prophet (pbuh) in his address. Skinner (1999) declared economic prosperity and political sustainability as two building blocks for the development of any society (p.88). As Cotterrell (1989) observed that a state as an association of human beings is established for the attainment of certain ends by certain means (p.34).

Another political achievement of the Prophet (pbuh) was that by way of his moderate politics, he (pbuh) conveyed the message that there is a strong relationship between legislation and the society in which the people live. Unlike Greeks who favored the class system and Jews who were victim of religious pride, Prophet (pbuh) introduced the principle of equality of all the human beings and eliminated class system. $\mathrm{He}$ declared the slaves, women and children as the most attention able segments of society who were totally neglected by the stake holders. It was political vision of the Prophet (pbuh) due to which he ordered Bilal to perform a sacred and the most honorable duty to pronounce Adan for five times a day. With his moderate politics, he (pbuh) created harmony among all the segments of the society and succeeded to establish a peaceful and happy society at Madinah and made all the tribes happy under his administrative and political policies irrespective of differences of religion, caste and race. As Smith, Bosworth (1967) pointed out that he (pbuh) was the messenger of Allah, and as well as Caesar and Pop of the Church. He was Caesar without the legions of the Caesar and pop without the Pop's pretensions; he was head of the Muslim state but without any army, any palace, any security guard, and salary etc" (p.92).

The other principle of the modern politics introduced in late $20^{\text {th }}$ century is that some of the states of the world must recognize an independent state (Salmond, p.167). The Prophet (pbuh) introduced this principle at Madinah before 1500 years by adopting policy of international relations, which drew the attention of the rest of the world towards Arab (. He (pbuh) wrote many letters to the King of Abyssinia, the Roman Empire (Heraculius), ruler of Egypt (Muqauqis, Jarih bin Mati), ruler of Bahrain (Munzir bin Sawi), king of Persia (Khusroe), ruler of Oman (Jafar and Abd bin Julkandi), ruler of Yemama (Houza bin ali) etc and invited them to the Oneness of God (Ibn Qayyim,1977). He further, established the principle of consultation as a sustainable 
tool for promoting good governance and development. He prohibited all types of prides by declaring all human beings equal and by declaring a slave his son by giving him status of a free man. Moreover, he (pbuh) condemns desire of power or authority by saying: "Not to quest for authority, for if you do so, you will be destroyed by it. If you are given power without asking for it, you shall be made to succeed" (Imam Bukhari, vol.1, p.23). Although the state of Madinah was under the direct control of the Prophet (pbuh), but he never behaved like a king or a ruler rather proved by his actions that he was just a messenger of Allah to establish law and order in the society. The only purpose behind his politics was just to set an example of a peaceful state on the earth in which everyone was equal before law so, that his followers may follow his (pbuh) steps and may succeed to establish law and order in the world. And We (Allah) have not sent you (Muhammad) except a blessing for the entire world (for all the times) (The Qur'an: 21:107). He (pbuh) proved himself as a role model in both aspects of his life, the religious aspect as a messenger of Allah and the worldly aspect as a human being. It is important to note that what actions and political steps taken by the Prophet (pbuh) were in accordance with the revealed principles of politics such as principle of equality of human beings, consultation, economic prosperity, peace and justice and foreign policy of a Muslim states (Naseem Razi, 2013).

\section{Section Three:}

\section{Contemporary Situation of the Modern Muslim Politics}

So far as concerned the issue of the Muslim population in the world, it is about 1.8 billion in some 57 countries. About $60 \%$ of the Muslims live in the Asia-Pacific region, while $20 \%$ in the North Africa and Middle East region (http//www.islam.com). Likewise, a substantial population of the Muslims is also living in Europe and North America for earning wealth or seeking knowledge. The population of the Muslims is increasing and it is estimated that it will be 1.6 of the world's 7 billion inhabitants, and will make up nearly a quarter of the world's population of an estimated 8.3 billion in the year 2030 (John, 2015).

It is however, matter of great concern that unlike past, at present most of Muslim countries are not democratic in their politics o and are governed by monarchs like Greeks indifferent of the socio-economic needs and political demands of their subjects (Shabbir Akhtar, p.210). Most of the Muslim countries are dependent for their economic survival on the interest-based loan of western countries (Naseem razi, 2014). Some Muslim states however, are self-sufficient in their economies but have forgotten the lesson of Muwkahat al-Madinah and seem indifferent of the poor economic conditions of their brethren and left them at the mercy of the western countries. It is this reason that the contemporary Muslim politics and political steps of Muslim political leaders are now uniformly condemned by the critics as a resolutely intolerant, potentially totalitarian, unmanageably anarchic and dangerously subversive etc (John L. Esposito,2011). 
Due to their lust for governance they failed to provide economic prosperity and political stability to their people. It led the poor, illiterate and jobless Muslims to involve into negative activities in the name of protection of the religion as in exchange they get assurance of economic prosperity for their families (Naseem Razi, Theological Extremism,2014).

John L. Esposito (2011) observed that among the major issues are political and social injustices, wealth disparity, authoritarian governments, repression, and corruption are great hurdles in the desires of the Muslims to be a more authentically rooted national, cultural and religious identity and values not dominated by and dependent on Western paradigms and culture" (p.55). The modern Muslim politics could not establish the political modesty and economic justice to satisfy an ordinary Muslim who anticipates Islam with honesty and political virtue. The Muslims are divided not only by boundaries but also divided into many religions based sectarian groups. Each of Muslim state has a different political, economic and cultural background. Politically, the Middle Eastern states are most backward as governed by a small elite (Naseem razi, Peaceful Co-Existence, p.119).

The Global Democracy Index 2016 studied 167 countries of the in the light of different forms of democracy. It shows that out of 167 countries of the world none of the Muslim states is among full and flawed democratic states. ${ }^{\dagger}$ Rather all of the Muslim states either are governed by way of authoritarian system of governance ${ }^{\star}$ or by way of hybrid regime. ${ }^{\S}$

Due to weak governance and lack of sincerity towards their nations, the Muslim political leaders could not establish peace and justice in their states even could not reduce illiteracy and poverty. The political instability, illiteracy and poverty have made the Muslims extremist and aggressive. The common Muslims do not have correct understanding of the religious norms, particularly regarding jihad and are easily trapped by those who for some political and worldly benefits start some

\footnotetext{
${ }^{\dagger}$ Full democratic are the states where civil liberties and basic political freedoms are respected, and a political culture is emerged on the basis of democratic principles. Among these states are North America and Western Europe. Flawed democratic countries are those where basic civil liberties are protected and elections are fair but may have some issues with respect to freedom of media, and governance. Among them are Latin America and Carribbeans.http//www.globaldemocracyindex/2016).

* Hybrid regimes are those states where substantial irregularities exist in elections and elections are not fair and free. Government use political pressure on the opposition. Judiciary and other organs of the state perform their functions under the influence of the ruling party. Australia, Asia, Central Europe, Eastern Europe and Sub-Sahara Africa are the states which are suffering from the issues of hybrid regime. http//www.globaldemocracyindex/2016).

$\S$ Authoritarian regimes which are governed under absolute dictatorship and political freedom is very restricted. Elections are not fair. Most of the Muslim Middle Eastern countries and North Africa are governed under dictatorship with few traditional democratic institutions.

http//www.globaldemocracyindex/2016)
} 
religious movement and invite the common Muslim to participate in a struggle for the protection of Islam. Yet, misguide them and causing the Muslims to be tagged of as terrorists. The Muslim political leaders have failed to play a moderate and practical role in the development of the contemporary politics of the world. Many of the Muslim states are confronting many serious issues regarding their survival in the presence of a global political and economic order given by their Prophet (pbuh).

The Human Development Report (2019) reveals that the Muslim states spend a very little on the human development (http://hdr.undp.org). Half of the global poverty resides at Muslim world (Muhammad Zubair Mughal, Tunisia, 2019). ${ }^{* *}$ The Annual Economic Report on the OIC Countries 2018 shows that the 57 OIC member countries produced only 10.9 per cent of the world total GDP (https://www.liveleak.com/9).

Talking about Pakistan, it is a religious based democratic state and $96.4 \%$ of its population is Muslim. It has very good constitution framed in the light of the objectives of Shari'ah but due to lack of political concern and political sincerity could not achieve its two basic goals, political stability and economic prosperity. The failure of economic prosperity led $60 \%$ of its population to live below the poverty line and the failure of political stability has made the state vulnerable to blast and target killing.

The Holy Prophet (pbuh) united more than 30 tribes in the bond of one nation by his moderate politics but the Pakistani political system could not reduce sectarianism, extremism and conflicts of the political interests.

\section{Conclusions and Recommendations}

This research thus concludes that almost all the political systems of the world have their origin in the religious norms and that the religion played an important role in the development of the politics of each society. It was during the middle era when the western countries thought to depart religion form politics due to exploitation of the common men, women, children and the governments by the Churches and pops in the name of religion. Although modern states avoid diplomatically giving religion an importance in their political policies by pronouncing religion as a private matter yet practically, all the states are following some religion directly or indirectly. For instance, India claims to be a secular state but all the state policies including educational policy reflect dominancy of Hinduism. Likewise, in European countries Christian dominancy can be witnessed in all the government policies.

It is also concluded that Muhammad (pbuh) was the founder of the moderate politics. At the time when the political systems of the world were based on the inequality of human beings and class system, the Prophet (pbuh) introduced the concept of equality

\footnotetext{
** Muhammad Zubair Mughal, Chief Executive Officer, AlHuda Centre of Islamic Banking and Economics while speaking at Islamic Microfinance Symposium that was held at Tunis - Tunisia which was organized by Tunis Association of Islamic Economics with association of Islamic Development Bank (IDB) and German Donor Agency GIZ.
} 
of human beings and eliminated all forms of discrimination and class system. Contrary to the prevailing system of monarchy and kingship, the Prophet (pbuh) introduced the concept of a liberal and moderate politics and democratic form of the government based on the principle of Shura. It was due to that moderate politics that no world faith has successfully and peacefully assimilated such a vast range of cultures and races as Islam done. Muwakaht al-Madinah leads that in case of necessity excessive property and wealth of the rich people can be taken by the government to give to poor but for this the contemporary political leadership must sacrifice first and should distribute their excessive properties among the poor.

It is thus suggested that the political leaders of the modern Muslim world should study the political steps of the Prophet (pbuh) in the light of the modern development of the politics. All the modern political techniques to achieve economic prosperity and to establish peace and order in fact have origin in the political steps of the Prophet (pbuh). To remove terrorism, to achieve economic prosperity and to establish peace and order, illiteracy should be eliminated, jobs and sources of earning should be created by mobilizing economic activities, justice should be provided free of cost and in easy manners, and the basic necessities of life should be provided on behalf of the states.

\section{References:}

A.P. Cowie. (2010). Oxford Advanced Learner's Dictionary. Oxford, Oxford University Press. Allamah Hafiz Ibn Qayyim. (1968). Zad al-Ma`ad. Cairo: Al-Matba'h al-Salfiyyah. vol.3.

Allamah Sayyed Suleman Nadawi. (1967). Seerah al-Nabi. India: n.p., 1967, Vo.1.

Allamah, Shibli Numani. (1988). Al-Farooq: Biography of Hadrat Umar.Lahore:

Maktabah Rahmaniyah.

Al-Qur'an al-Kareem.

Aristotle. (1948). The Politics. transl. R. G. Barker. Oxford, n. p.

Aristotle. (1956). The Nicomachean Ethics. trans., H. Rackham, M. A., London,

William Heinemann Ltd. At www.googlebook.com. Last visited on 1-06-19.

Clive Archer. (1983). Key Concepts in International Relations: International

Organizations. London: George Allen \& Unwin.

Cotterrell, R., (2006). The Politics of Jurisprudence. London: Butterworth.

Cownie, F., and A. Bradeny. (2004). The English Legal System in Context. London:

Lexis Nexis Butter worth's.

David Held. (2002). Democracy and the Global Order. Cambridge: Polity Press.

Dr. Naseem Razi. (2015). "Peaceful Co-existence between Muslims and non-Muslims:

An Analysis of Pakistani Society in the Light of Seerah Muhammad (pbuh)". International Journal of

Sciences: Basic and Applied Research. ISSN 2307-4531. Vol.23,

@ http://gssrr.org/index.php?journal=JournalOfBasicAndApplied.

Dr. Naseem Razi. (December, 2014). Theological Extremism and its Effects: Pakistan

Perspective". Journal of Social Science for Policy Implications. Vol. 2, No. 4, pp. 59-72. ISSN: 23342900 (Print), 2334-2919 (Online). USA: American Research Institute for Policy Development. DOI: 10.15640/10.15640/jsspi.v2n4a4. URL: http://dx.doi.org/10.15640/jsspi.v2n4a4.

Earner Barker. (1959). Greek Political Theory: Plato and his Predecessors. London.

Edger, Bodenheimer. (1977). Jurisprudence: The Philosophy and Method of the Law,

London, n.p.

Edward Gibbon. ed.,(1949). The History of the Decline and fall of Roman Empire. 
H.W. Brands. (2000). The First American: The Life and Times of Benjamin Franklin, USA, Franklin Institute.

Ibn Hashsham, Abu Hamid 'Abdul Malik. (1978). Seerah al-Nabawiyyah.Cairo:

Matb'ah Hadithah.Vol.1.

Ibn Ishaq. (1968). The Life of Muhammad (PBUH), trans., Guillaume, Karachi:

Oxford University Press.

Ibn Sa'd, Abu 'Abd Allah Muhammad bin Sa d. (1388 A.H). Tabaqat al-Kubra. Cairo:

Dar al-Tehrir. Vol.1.

Imam Bukhari, Muhammad bin Isma'il al-Bukhari. (1989). Al-Jame’ al-Sahih.

Lahore: 7 Aibak Road. Hadith no.3556.

J. H. Baker. (1998). An Introduction to English Legal History. London: n.p.

J. L., Brierly. (2001). The Law of the Nations. London: n.p.

J. Walter Jones. (1967). The Law and Legal Theory of the Greeks. Oxford: n.p.

Jin-Hyun Paik \& Seok-Wool Leo. (2006). Asian Approaches to International Law and

the Legacy of Colonialism.London,n.p.

John L. Esposito. (2007). "Contemporary Islam: Challenges and Opportunities",

Oxford Islamic Studies online. Oxford University

http://www.oxfordislamicstudies.com/article/book/islam-9780195107999/islam-chapter-15. Last

visited on 31-08-19.

Morrison, W. J., Gearey A. \& K. Malleson. (2004). Common Law Reasoning and

Institutions, London, University of London Pres.

Muhammad Hamidullah. (1975). The First Written Constitution in the World.

Lahore.

Muhammad Hamidullah. (1993). The Emergence of Islam, ed. \& trans, Afzal Iqbal.

Islamabad: Islamic Research Institute.

Muhammad Hamidullah. Political Life of the Messenger of God. Islamabad.

Naeem Siddiqui.(1960). Muhsin-e-Insaniyat, Lahore, Islamic Publications.

Naseem Razi. (December,2016). Islamic Law Vis a Vis Common Law: A Historical

Analysis in terms of Rigidity and Flexibility". Hamdard Islamicus. Karachi: Hamdard Foundation.

Vol.39.No.4.

Naseem Razi. (June, 2013). "Democracy as a Political System of Governance: An

Analysis in the Light of the Fundamental Qur'anic Principles of Governance”. Journal of Asian

Development Studies. ISSN 2304-375X., Vol. 2, Issue 2. pp.94-107.

Pollock, F. \& F. W. Maitland. (1929). History of English Law. Cambridge:

Cambridge University Press.

Pound, Roscoe. (1987). An Introduction to the Philosophy of Law. London:n.p. William N. Eskridge.

(2001). Jr., Dynamic Statutory Interpretation.Cambridge:

University Press.

Shabbir Akhtar. (2011). Islam as Political Religion: The future of an imperial faith,

London: Taylor and Francis Group.

Skinner, Q., (1989). Political Innovations and Conceptual Change. Cambridge:

University Press.

Smith, Bosworth. (1967). Muhammad and Muhammadanism. London: n. p.

Steven Fish, \& Robin Brooks. (2012). "Civil Society, Defining Democracy,

Democratic Consolidation, Political Picture". Democratic Journal of Democracy. Vol.11.

Sydney Bailey \& Sam Daws. (1998). The United Nations: A Concise Political Guide,

UK, n.p.

Wilfred E. Rumble. (1987). The Thought of John Austin: Jurisprudence, Colonial

Reform and the British Constitution. London: Athlone Press. 